\title{
Pressure-induced Connective Tissue Synthesis in Pulmonary Artery Segments Is Dependent on Intact Endothelium
}

\author{
Carol A. Tozzi, George J. Poiani, Andrea M. Harangozo, Charles D. Boyd, and David J. Riley
}

Departments of Medicine and Surgery, University of Medicine and Dentistry of New Jersey-Robert Wood Johnson Medical School, New Brunswick, New Jersey 08903-0019; and The Department of Medicine, Lyons Veterans Administration Medical Center, Lyons, New Jersey 07939

\begin{abstract}
Physiologic stimuli of connective tissue accumulation in pulmonary vascular remodeling are poorly defined. We postulated that increased pressure within central pulmonary arteries is a stimulus for connective tissue synthesis and the response is dependent on an intact endothelium. Mechanical tension equivalent to $50 \mathrm{mmHg}$ pressure was applied for $4 \mathrm{~h}$ to isolated rat main pulmonary arteries (endothelium intact or removed), and incorporation of $\left[{ }^{14} \mathrm{C}\right]$ roline into collagen, $\left[{ }^{14} \mathrm{C}\right]$ valine into elastin, $\left[{ }^{3} \mathbf{H}\right]$ thymidine into DNA and pro $\alpha 1(I)$ collagen mRNA levels were measured. In intact vessels, tension induced synthesis of collagen $\left(3.1 \pm 0.4\right.$ vs. $2.3 \pm 0.5[\mathrm{SEM}] \mathrm{dpm} \times 10^{2}\left[{ }^{14} \mathrm{C}\right]-$ hydroxyproline/[mg protein $\cdot h])(n=10)$ and elastin $(6.1 \pm 2.4$ vs. $2.9 \pm 0.4 \mathrm{dpm} \times 10^{3}\left[{ }^{14} \mathrm{C}\right]$ valine/[mg protein $\left.\left.\cdot h\right]\right)(n=5)$ (both $P<0.05$ ). Steady state mRNA levels of pro $\alpha 1$ (I) collagen were also increased by tension ( $46 \mathrm{vs} .30 \times 10^{2} \mathrm{dpm}$ hybridized/100 ng total RNA). However, the stimulus did not increase $\left[{ }^{3} \mathbf{H}\right]$ thymidine incorporation into DNA. In denuded vessels, tension had no effect on connective tissue synthesis or mRNA level of pro $\alpha 1(I)$ collagen. Messenger RNA levels for $\mathrm{v}$-sis were induced by tension in intact but not denuded vessels. Our findings establish that induction of vascular connective tissue synthesis by mechanical tension is dependent on an intact endothelium.
\end{abstract}

\section{Introduction}

Chronic pulmonary hypertension is associated with marked fibrocellular changes in the pulmonary vascular bed (1). The stimuli for these anatomic changes are poorly understood, but one stimulus common to many forms of pulmonary hypertension is altered mechanical forces from elevated blood pressure or increased flow. Vascular structures are modified by mechanical forces (2), and several mechanisms have been proposed. For example, high pressure may act through shear stress to damage endothelium and activate platelets which in turn

Presented at the 30th Annual Aspen Lung Conference, Aspen, CO, June 1987, and published in abstract form in 1988 (Chest. 93(Suppl.):169S-170S).

Address reprint requests to Dr. Riley, Division of Pulmonary and Critical Care Medicine, UMDNJ-Robert Wood Johnson Medical School, One Robert Wood Johnson Place, CN 19, New Brunswick, NJ 08903-0019.

Received for publication 28 November 1988 and in revised form 16 March 1989.

J. Clin. Invest.

(C) The American Society for Clinical Investigation, Inc.

0021-9738/89/09/1005/08 $\$ 2.00$

Volume 84, September 1989, 1005-1012 might lead to the structural changes $(3,4)$, or there may be increased passage of serum factors by high pressure (5). Alternatively, certain cells of the blood vessel wall might respond to the applied load by producing growth or differentiation factors that influence surrounding vascular cells (6), or cells may respond directly to mechanical forces by elaborating structural or contractile proteins (7).

In this study, we tested whether static mechanical tension applied to pulmonary artery segments in vitro stimulates cell proliferation and production of connective tissue proteins. We also examined whether the endothelial cell modulates this process by comparing the responses in intact segments to those with the endothelium removed. Short-term $(4 \mathrm{~h})$ tension stimulated collagen and elastin synthesis as well as steady-state mRNA levels for type I procollagen, but we were unable to detect increased cell division. The mRNA level for v-sis, a protooncogene that encodes a peptide highly homologous to the B chain of platelet-derived growth factor (PDGF) ${ }^{1}(8)$, was enhanced by mechanical stimulation. Removal of the endothelium ablated these responses. Our findings suggest that short-term mechanical tension stimulates release of endothelial-derived factors, which increase production of extracellular matrix proteins by cells of the blood vessel wall.

\section{Methods}

Materials. Outbred 6-wk-old male Sprague-Dawley (Crl:CD[SD]BR) rats weighing 200-270 g were obtained from Charles River Breeding Laboratories, Wilmington, MA. Solutions were Krebs-Ringer bicarbonate (KRB) $\left(118 \mathrm{mM} \mathrm{NaCl}, 4.7 \mathrm{mM} \mathrm{KCl}, 1.2 \mathrm{mM} \mathrm{KH}_{2} \mathrm{PO}_{4}, 1.2\right.$ $\mathrm{mM} \mathrm{MgSO}_{4} \cdot 7 \mathrm{H}_{2} \mathrm{O}, 2.5 \mathrm{mM} \mathrm{CaCl}_{2}, 25 \mathrm{mM} \mathrm{NaHCO}_{3}, \mathrm{pH} 7.4$ ), modified KBR (128 mM NaCl, $6 \mathrm{mM} \mathrm{KCl}, 18 \mathrm{mM} \mathrm{Na}_{2} \mathrm{HPO}_{4}, 16 \mathrm{mM}$ $\left.\mathrm{KH}_{2} \mathrm{PO}_{4}, 1.5 \mathrm{mM} \mathrm{MgCl}, 5 \mathrm{mM} \mathrm{NaHCO}, \mathrm{pH} 7.4\right)$ and $1 \times \mathrm{SSC}(150$ $\mathrm{mM} \mathrm{NaCl}$ and $15 \mathrm{mM}$ trisodium citrate). Denhardt's solution and 3-( $N$-morpholino)propanesulfonic acid (MOPS) solution were prepared using standard methods (9). L-Proline, transfer RNA (type X, from baker's yeast), isoamyl alcohol, spermidine, herring sperm DNA, $[ \pm]$-norepinephrine and acetylcholine chloride were purchased from Sigma Chemical Co., St. Louis, MO. Sarkosyl was obtained from ICN Biomedicals, Inc., Plainview, NY and Sephadex G-50 was from Pharmacia Fine Chemicals, Piscataway, NJ. Formamide, SDS, cesium chloride, DTT, guanidinium isothiocyanate, agarose, Tris- $\mathrm{HCl}$, and Eco RI, Ava I, Bam HI, Hind III, Xba I and Pst I restriction endonucleases were supplied by International Biotechnologies, Inc., New Haven, CT. $\left[{ }^{32} \mathrm{P}\right]$ UTP $(3,200 \mathrm{mCi} / \mathrm{mmol})$ was purchased from ICN Radiochemicals, Irvine, CA, $\left[{ }^{14} \mathrm{C}\right]-\mathrm{L}-$ proline $(260 \mathrm{mCi} / \mathrm{mmol}),\left[{ }^{14} \mathrm{C}\right]$ valine $(0.25 \mathrm{mCi} / \mathrm{mmol})$ and $\left[{ }^{3} \mathrm{H}\right]$ thymidine $(78.8 \mathrm{Ci} / \mathrm{mmol})$ from New England Nuclear, Boston, MA. ATP, GTP, CTP, RNAsine ribonuclease inhibitor, SP6 RNA polymerase, and DNAse were obtained from Pro-

1. Abbreviations used in this paper: LDH, lactate dehydrogenase; PDGF, platelet-derived growth factor; TGF- $\beta$, transforming growth factor $\beta$. 
mega Biotec, Madison, WI. Calf thymus DNA was supplied by Calbiochem-Behring Corp., San Diego, CA. Nitrocellulose (BA85, 0.45 $\mu \mathrm{m})$ was purchased from Schleicher \& Schuell, Keene, NH. Oligo(dT)-cellulose columns were obtained from Collaborative Research, Bedford, MA. Liquid scintillation fluid was Liquiscint purchased from National Diagnostics, Somerville, NJ. Kodax X-Omat AR X-ray film was purchased from E. I. Du Pont de Nemours and Co., Wilmington, DE.

Animals. Animals were kept for 1 wk before study and were fed water and food ad lib. Approximately two to three animals in each group were used to measure right ventricular pressure to check that the animals were normotensive. Mean right ventricular pressure (measured in animals anesthetized with $50 \mathrm{mg} / \mathrm{kg}$ i.p. sodium pentobarbital), hematocrit and the ratio of weights of the cardiac ventricles were measured as previously described (10).

Preparation of vessel segments. Fresh segments of pulmonary artery, aorta and jugular vein were obtained from separate animals. Two adjacent segments (2-3 mm in length) were excised from the lower third of the thoracic aorta and the main pulmonary artery trunk; one segment $(5 \mathrm{~mm})$ was removed from the right and left jugular veins. Tissues were washed twice in PBS and weighed. Each segment of the pair was randomly allocated to a tension or control group. The segment with tension applied was placed on two opposing stainless steel hooks, one of which was fixed and the other connected to a force displacement transducer (FTO 3C; Grass Medical Instruments, Quincy, MA). Both segments were placed in a $10-\mathrm{ml}$ water jacketed organ bath containing $5 \mathrm{ml}$ of KRB and additional components (see below), $37^{\circ} \mathrm{C}$, and aerated with $95 \% \mathrm{O}_{2}, 5 \% \mathrm{CO}_{2}$. The segments were equilibrated for $1 \mathrm{~h}$ without tension. After equilibration, the force displacement transducer was adjusted until the desired tension was obtained, and the output was continuously recorded (Dynagraph; Beckman Instruments, Schiller Park, IL). Slight adjustments were made to maintain constant tension during the experiment. The control segment was placed on a stainless steel hook and counterweighed with an opposing weight equivalent to $10 \mathrm{mmHg}$ pressure for the pulmonary artery and jugular vein; $80 \mathrm{mmHg}$ was used for the aorta. To simulate hypertension, tensions equivalent to 25,50 , or $100 \mathrm{mmHg}$ pressure (pulmonary artery), $80 \mathrm{mmHg}$ (jugular vein), or $160 \mathrm{mmHg}$ (aorta) were applied. Static tension was applied for $4 \mathrm{~h}$. In other paired segments, the endothelium was removed by gently rubbing the lumen of the vessel with a cotton-tipped probe. Results between paired segments with and without endothelium were compared.

Mechanical tension. A tangential load was applied to each segment of the pulmonary artery to produce a circumferential wall tension equivalent to that produced by a particular blood pressure (11). The tangential load required to achieve an equivalent blood pressure was calculated for each segment based on tissue wt and cross-sectional area. Cross-sectional area was estimated from the weight and length (unstretched) of each segment using the following formula: area $=w t$ (g)/(length $[\mathrm{cm}] \times 1.05 \mathrm{~g} / \mathrm{cm}^{3}$ ). The tangential load required to achieve an equivalent blood pressure was calculated using the following equation: pressure $=(980 \mathrm{dyn} / \mathrm{g} \times$ tension $\left.[\mathrm{g}]) / \mathrm{area}\left[\mathrm{cm}^{2}\right]\right)(11)$. The internal radius of the segment was estimated by measuring half the internal diameter using a calibrated eyepiece attached to a microscope. Circumferential wall tension was calculated as the product of blood pressure and radius (12).

Collagen synthesis. Collagen synthesis was measured by the incorporation of $\left[{ }^{14} \mathrm{C}\right]$ proline into hydroxyproline using the procedure of Juva and Prockop (13). The incubation medium contained $5.6 \mathrm{mM}$ dextrose, $0.5 \mathrm{mM}$ ascorbic acid, $0.9 \mathrm{mM}$ L-proline and $10 \mu \mathrm{Ci} / \mathrm{ml}$ $\left[{ }^{14} \mathrm{C}\right.$ ]proline in KRB. After application of tension for $4 \mathrm{~h}$, the tissue was washed four times in KRB, homogenized (Polytron; Brinkmann Instruments, Westbury, NY) and dialyzed against 4 liters deionized water with twice daily exchanges for $3 \mathrm{~d}$ at $4^{\circ} \mathrm{C}$. The content of each bag was lyophilized and hydrolyzed in $6 \mathrm{~N} \mathrm{HCl}$ at $116^{\circ} \mathrm{C}$ for $48 \mathrm{~h}$. Collagen synthesis was estimated by measuring $\left[{ }^{14} \mathrm{C}\right]$ hydroxyproline obtained by silicic acid column extraction of the acid hydrolyzed aliquots (13). Incorporation of $\left[{ }^{14} \mathrm{C}\right]$ proline into $\left[{ }^{14} \mathrm{C}\right]$ hydroxyproline was determined to be linear over the 4-h incubation period (data not shown). Results were expressed as dpm $\left[{ }^{14} \mathrm{C}\right]$ hydroxyproline/(mg protein $\cdot h)$.

Insoluble elastin synthesis. Synthesis of insoluble elastin was estimated by a modification of the method of Keeley and Johnson (14). Each segment was incubated in $10 \mathrm{ml}$ KRB supplemented with 5.6 $\mathrm{mM}$ dextrose, $0.5 \mathrm{mM}$ ascorbic acid and $2.4 \mathrm{mM}$ L-valine, $\mathrm{pH} 7.4$, under $95 \% \mathrm{O}_{2}, 5 \% \mathrm{CO}_{2}$ in the organ bath at $37^{\circ} \mathrm{C}$ for $30 \mathrm{~min}$. The tissue was washed twice in valine-free incubation medium, put under tension and incubated with $5 \mathrm{ml} \mathrm{KRB}$ containing $10 \mu \mathrm{Ci} / \mathrm{ml}\left[{ }^{14} \mathrm{C}\right]-$ valine for $4 \mathrm{~h}$. The tissue was rinsed with KRB containing $4.0 \mathrm{mM}$ valine and added to $1.0 \mathrm{ml}$ of $0.01 \mathrm{M}$ phosphate buffer containing $1.0 \%$

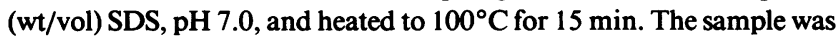
centrifuged at $10,000 \mathrm{~g}$ at $25^{\circ} \mathrm{C}$ for $10 \mathrm{~min}$, and the supernatant removed. The extraction was continued overnight in the same buffer at $20^{\circ} \mathrm{C}$, centrifuged, and the tissue was further extracted in $70 \%$ formic acid and $1 \%(\mathrm{wt} / \mathrm{vol})$ cyanogen bromide $(\mathrm{CNBr})$ overnight at $20^{\circ} \mathrm{C}$ and centrifuged. The residue was hydrolyzed in $6 \mathrm{~N} \mathrm{HCl}$ at $100^{\circ} \mathrm{C}$ for $48 \mathrm{~h}$, evaporated, lyophilized and reconstituted in $1.0 \mathrm{ml}$ of water. The radioactivity in a $0.1-\mathrm{ml}$ aliquot was determined at $95 \%$ efficiency using a liquid scintillation counter (Tri Carb; Packard Instruments, Downers Grove, IL). The incorporation of $\left[{ }^{14} \mathrm{C}\right]$ valine into insoluble elastin was found to be linear over a 4-h period as determined by the level of $\left[{ }^{14} \mathrm{C}\right]$ valine in tissue samples during the incubation period. The residue after $\mathrm{CNBr}$-formic acid extraction has been previously confirmed to be insoluble elastin by amino acid analysis. Radioactivity of the residue was taken as a measure of the insoluble elastin synthesis during the incubation period. The results are expressed as $\mathrm{dpm}\left[{ }^{14} \mathrm{C}\right]$ valine $/(\mathrm{mg}$ protein $\cdot \mathbf{h})$.

Protein content. For tissues used for the collagen assay, protein content was measured in a $0.2-\mathrm{ml}$ aliquot of the hydrolysate using the ninhydrin method (15) with leucine as standard. For tissues used for elastin synthesis, protein content was measured using a Coomassie brilliant blue G-250 dye binding assay using bovine plasma gamma globulin as standard (16). This protein assay was used in the elastin studies since SDS interferes with the ninhydrin assay.

$\left[{ }^{3} \mathrm{H}\right]$ Thymidine incorporation. To measure $\left[{ }^{3} \mathrm{H}\right]$ thymidine incorporation, separate tissues were incubated with KRB containing 5.6 $\mathrm{mM}$ dextrose and $40 \mu \mathrm{Ci} / \mathrm{ml}\left[{ }^{3} \mathrm{H}\right]$ thymidine. After a 4-h incubation, DNA was extracted from tissue in $10 \mathrm{mM}$ PBS containing $1 \%$ SDS, $\mathrm{pH}$ 7.0, and heating to $100^{\circ} \mathrm{C}$ for $10 \mathrm{~min}$ followed by a second extraction in the same buffer at $20^{\circ} \mathrm{C}$ for $12 \mathrm{~h}$. Radioactivity was counted in the supernatant, and DNA was measured from aliquots of the SDS-phosphate extract using a fluorometric method (17) using calf thymus DNA as standard. Fluorescence was read on a fluorometer (Turner; Amsco Instruments, Palo Alto, CA) at excitation of $420 \mathrm{~nm}$ and emission frequency of $510 \mathrm{~nm}$. Results were expressed as dpm $\left[{ }^{3} \mathrm{H}\right]$ thymidine/DNA.

Lactate dehydrogenase activity. Lactate dehydrogenase (LDH) activity was measured in a $2.6-\mathrm{ml}$ aliquot of the incubation medium using the method of Wroblewski and LaDue (18). A positive control representing $100 \%$ release from tissue was prepared by pulverizing tissue $(5-8 \mathrm{mg}$ ) in liquid nitrogen and resuspending in $3.8 \mathrm{ml} \mathrm{KRB}$ containing $0.2 \%$ Triton $\mathrm{X}-100$ (vol/vol). Samples were centrifuged $(10,000 \mathrm{~g})$ for $5 \mathrm{~min}$, and a $0.1-\mathrm{ml}$ aliquot of the supernatant was used. The assay was performed at $24^{\circ} \mathrm{C}$ in a spectrophotometer (model 552; Perkin-Elmer, Eden Prairie, MN). Results were expressed as a percentage of total amount released from tissue ([amount of LDH in medium/LDH in tissue + medium] $\times 100$ ).

Endothelium-dependent relaxation. In selected vessels, we assessed whether the endothelium was functionally intact by demonstrating endothelium-dependent relaxation in response to acetylcholine (19). The vessels were prepared as above and placed in $10 \mathrm{ml}$ of modified $\mathrm{KRB}$ containing $10 \mathrm{mM}$ dextrose, $\mathrm{pH} 7.4$, at $37^{\circ} \mathrm{C}$ aerated with $95 \%$ $\mathrm{O}_{2}$ and $5 \% \mathrm{CO}_{2}$. The rings were connected to force transducers, and changes in isometric tension were recorded. The rings were precontracted with norepinephrine $\left(10^{-7}\right.$ to $\left.10^{-8} \mathrm{M}\right)$ until the optimal lengthtension relationship was reached. Rings were washed and allowed to 
equilibrate for $45 \mathrm{~min}$ after which acetylcholine $\left(10^{-7}\right.$ to $10^{-5} \mathrm{M}$ final concentration) was added. Each relaxation was expressed as a percentage of the contraction in response to norepinephrine. For statistical calculations, the concentration of the agonist evoking 50\% relaxation $\left(\mathrm{IC}_{50}\right.$ value) was used.

Scanning electron microscopy. Representative segments of pulmonary artery were processed for scanning electron microscopy to assess the endothelial cell layer. In some rings, the endothelium was removed by gentle rubbing with a cotton-tipped probe. Rings were placed under mechanical tension (equivalent to $50 \mathrm{mmHg}$ ) for $4 \mathrm{~h}$ as described above. After application of tension, tissues were opened longitudinally and placed in $2.5 \%$ glutaraldehyde buffered with $0.1 \mathrm{M}$ sodium caco-

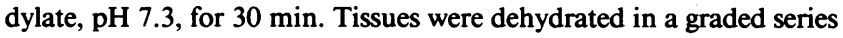
of ethyl alcohols, dried, mounted and coated with gold-palladium. Tissues were visualized at $1500 \times$ with a scanning electron microscope (model 1400; Amray, Inc., Bedford, MA).

Extraction of RNA. Tissue segments were immediately frozen at $-70^{\circ} \mathrm{C}$ after application of tension. Pulmonary artery, aorta, and jugular vein tissues were pooled from 15 to 20 animals and minced with a sterile scalpel. Total RNA was extracted using a guanidinium isothiocyanate-cesium chloride extraction procedure modified from that described by Glisin and associates (20). The minced tissue was added to 5 vol of an ice-cold extraction buffer ( $4 \mathrm{M}$ guanidinium isothiocyanate, 5 $\mathrm{mM}$ sodium citrate, $0.1 \mathrm{M} \beta$-mercaptoethanol, $0.5 \%$ [wt/vol] sarkosyl, $\mathrm{pH} 7.0$ ) and homogenized at $10,000 \mathrm{rpm} .1 \mathrm{~g} \mathrm{CsCl}$ was added per 2.5 $\mathrm{ml}$ of homogenate, and the mixture was layered on top of a $\mathrm{CsCl}$ cushion (5.7 M CsCl, 0.1 M EDTA, pH 7.5) and centrifuged at 35,000 rpm for $16 \mathrm{~h}$ at $20^{\circ} \mathrm{C}$ (model L8-70M ultracentrifuge; Beckman Instruments, Fullerton, CA). RNA pellets were dissolved in $10 \mathrm{mM}$ Tris-HCl, 5 mM EDTA, 1\% (wt/vol) SDS, pH 7.4, extracted with an equal volume of chloroform:butanol $(4: 1)$, precipitated with ethanol, and dissolved in deionized water. The amount of RNA was determined spectrophometrically at $260 \mathrm{~nm}$. Poly(A) ${ }^{+}$RNA was prepared from total RNA using an oligo(dT)-cellulose column according to the manufacturer's instructions. Stock concentrations were stored at $-70^{\circ} \mathrm{C}$.

Preparation of radiolabeled RNA transcripts. Linearized SP6 recombinants containing cDNA fragments for human pro $\alpha 1$ (I) procollagen, v-sis protooncogene and $\gamma$-actin were used to synthesize ${ }^{32} \mathrm{P}$-labeled single-stranded RNA transcripts using a commercially available kit (Riboprobe, Promega-Biotec, Madison, WI) (21). Transcripts were generated by incubating $1 \mu \mathrm{g}$ of the SP6 recombinant DNA in a 50- $\mu \mathrm{l}$ reaction mixture containing $40 \mathrm{mM}$ Tris- $\mathrm{HCl}, \mathrm{pH} 7.5,6 \mathrm{mM} \mathrm{MgCl}_{2}, 2$ $\mathrm{mM}$ spermidine, $0.5 \mathrm{mM}$ ATP, $0.5 \mathrm{mM} \mathrm{GTP}, 0.5 \mathrm{mM} \mathrm{CTP}, 200 \mu \mathrm{Ci}$ $\left[{ }^{32} \mathrm{P}\right] U T P, 0.01 \mathrm{M}$ DTT, $50 \mathrm{U}$ RNAsine ribonuclease inhibitor, and 10 U SP6 RNA polymerase. The reaction mixture was incubated for $1 \mathrm{~h}$ at $37^{\circ} \mathrm{C}$; $100 \mu \mathrm{g}$ RNA carrier, $50 \mathrm{U}$ RNAsine, and $0.5 \mu \mathrm{g}$ DNAse were added, and the reaction mixture was incubated at $37^{\circ} \mathrm{C}$ for $15 \mathrm{~min}$. The reaction mixture was extracted with a phenol chloroform isoamyl alcohol solution (50:50:1), and the radiolabeled RNA was separated by chromatography on a Sephadex G-50 column and ethanol precipitated. The specific activity of the ${ }^{32}$ P-labeled RNA was determined, and about $8 \times 10^{7} \mathrm{dpm}$ was used in the hybridization procedure.

Dot blot hybridization assay of total RNA. Dot (or "slot") blot hybridization was carried out according to the method of Pierce and associates (22) with modifications. For each experimental and control group, filters were prepared on the same day and were hybridized using the same solutions and probes. Total RNA was serially diluted (100-500 ng total RNA per well) and applied to nitrocellulose presoaked with $10 \times$ SSC and $1 \%$ formaldehyde using an apparatus for dot hybridization (Minifold II; Schleicher \& Schuell). Samples containing $200 \mathrm{ng}$ yeast tRNA were applied to each filter to determine nonspecific binding of the probe. Each slot was washed three times with $200 \mu \mathrm{l}$ of $10 \times \mathrm{SSC}$, the filter was air dried, baked at $80^{\circ} \mathrm{C}$ under vacuum for $2 \mathrm{~h}$ and sealed in a clear plastic bag. The prehybridization and hybridization solution consisted of $5 \times \mathrm{SSC}$ and $1 \%(\mathrm{wt} / \mathrm{vol}$ ) sarkosyl. Hybridization was performed by adding the radiolabeled probe and hybridization buffer to the filter and incubating for $12-18 \mathrm{~h}$ at $65^{\circ} \mathrm{C}$ with gentle shaking. After washing twice at $65^{\circ} \mathrm{C}$ with a posthybridization buffer containing $2 \times$ SSC and $0.5 \%$ (wt/vol) sarkosyl and twice with $2 \times$ SSC for $10 \mathrm{~min}$ each at $65^{\circ} \mathrm{C}$, the nitrocellulose was exposed to $\mathrm{x}$-ray film in a cassette backed by intensifying screens (Lightning Plus, DuPont de Nemours \& Co., Wilmington, DE) at $-70^{\circ} \mathrm{C}$ for $10 \mathrm{~min}$ to $3 \mathrm{~h}$ to observe differences in the amounts of individual probes hybridized.

Quantitation of radioactivity. Quantitation of filter-bound radioactivity was carried out by scanning the nitrocellulose filter using a computer-assisted beta-scanner (Automated Microbiology System, Inc., San Diego, CA). This scanner counts with an efficiency of $18 \%$ compared to counts obtained by a scintillation counter (model LS 1801; Beckman Instruments, Inc.). The results were corrected for the efficiency of the beta-scanner and quantitated by subtracting the nonspecific binding (tRNA sample). Results were plotted as disintegrations per minute per slot against total RNA applied per slot. Linearity of the plot was determined by linear regression analysis, and plots were accepted if the standard error of the estimate $(r)$ was $>0.95$.

Northern blot analysis. RNA was denatured in a solution containing $2 \mathrm{M}$ formaldehyde, $1 \times$ MOPS, and $50 \%$ formamide by heating to $65^{\circ} \mathrm{C}$ for $10 \mathrm{~min}$, followed by quick chilling on ice. Total RNA $(10 \mu \mathrm{g})$ was applied for the pro $\alpha 1$ (I) collagen and $\gamma$-actin probes and poly(A) ${ }^{+}$ RNA ( $2 \mu \mathrm{g})$ for the v-sis probe. Samples were applied to a $1.0 \%$ (wt/vol) agarose gel and electrophoresed in $1 \times$ MOPS, $50 \mathrm{mM}$ sodium acetate, and $1 \mathrm{mM}$ EDTA, using a horizontal gel electrophoresis unit (model MPH; International Biotechnologies, Inc., New Haven, CT). RNA was transferred to a nitrocellulose filter using a plastic transfer system (Ann Arbor Plastics, Ann Arbor, MI) overnight at $4^{\circ} \mathrm{C}$ in the presence of $10 \times$ SSC. After transfer, the nitrocellulose was briefly rinsed in $2 \times$ SSC and baked at $80^{\circ} \mathrm{C}$ under vacuum for $2 \mathrm{~h}$. The filter was soaked in $3 \times$ SSC for $5 \mathrm{~min}$ and prehybridized at $65^{\circ} \mathrm{C}$ for $1 \mathrm{~h}$ in a solution of $3 \times$ SSC, $10 \times$ Denhardt's solution, $0.1 \%$ (wt/vol) SDS, and $10 \mathrm{mg} / \mathrm{ml}$ denatured herring sperm DNA. Hybridization was performed with $\sim 200 \mathrm{ng}$ of ${ }^{32} \mathrm{P}$-labeled cDNA probes (radiolabeled by the Ribroprobe technique to a specific activity in excess of $1 \times 10^{8} \mathrm{dpm} / \mu \mathrm{g}$ ) in $8-12 \mathrm{ml}$ of the hybridization solution mentioned above at $65^{\circ} \mathrm{C}$ for $24-40 \mathrm{~h}$. After hybridization, the filters were washed at $65^{\circ} \mathrm{C}$ four times in a buffer consisting of $3 \times$ SSC, 10× Denhardt's solution, and $0.1 \%$ (wt/ vol) SDS, sealed in plastic bags, and exposed to $x$-ray film in a cassette with image intensifiers at $-70^{\circ} \mathrm{C}$ for 3-24 $\mathrm{h}$.

Preparation of recombinant plasmids. A human pro $\alpha$ 1(I) procollagen cDNA, Hf677 (23), generously donated by Dr. D. J. Prockop, Jefferson Medical College, Philadelphia, PA, was digested with Eco RI. A 1,500-bp restriction fragment containing a DNA sequence coding for most of the carboxyl propeptide and part of the helical region of human pro $\alpha 1$ (I) collagen was isolated and subcloned into a PSP 65 vector. Recombinants containing correctly oriented DNA inserts were linearized by digestion with Ava I. A human $\gamma$-actin $\mathrm{CDNA}$, pHF $\gamma$-A3'ut (24), generously donated by Dr. P. Gunning, Stanford University School of Medicine, Palo Alto, CA, was digested with Bam HI-Hind III, and a 700-bp restriction fragment was inserted into the SP6 Riboprobe vector and linearized with Hind III. This restriction fragment contains sequences coding for part of the $3^{\prime}$ nontranslated region of human $\gamma$-actin mRNA. A $950 \mathrm{bp} \mathrm{Xba} \mathrm{I-Pst} \mathrm{I} \mathrm{fragment} \mathrm{of} \mathrm{the} \mathrm{retroviral}$ transforming gene v-sis (25) was obtained from Oncor, Inc., Gaithersberg, MD, and was subcloned into the SP6 Riboprobe vector.

Experimental protocols. Tissues from separate animals were used to measure collagen synthesis, elastin synthesis, $\left[{ }^{3} \mathrm{H}\right]$ thymidine incorporation into DNA, lactic dehydrogenase activity and steady-state mRNA levels for pro $\alpha 1$ (I) collagen, the v-sis proto-oncogene and $\gamma$ actin. For collagen and elastin synthesis and $\left[{ }^{3} \mathrm{H}\right]$ thymidine incorporation, two groups (intact and denuded endothelium) were studied at 50 and $10 \mathrm{mmHg}$. For lactic dehydrogenase activity, two groups were used: intact segments at 250 and $50 \mathrm{mmHg}$ and denuded segments at 0 and $50 \mathrm{mmHg}$.

Eight protocols each consisting of paired groups were used for steady-state mRNA levels for pro 1 (I) collagen and 6 for $\gamma$-actin (Table I). Group 1 was used to assess reproducibility of collagen and actin measurements under control conditions (10 $\mathrm{mmHg}$ tension). Groups 2 and 3 were duplicate studies to test the effect of $50 \mathrm{mmHg}$ 


\begin{tabular}{|c|c|c|c|c|c|c|c|c|c|c|}
\hline \multirow[b]{3}{*}{ Group } & & & \multicolumn{5}{|c|}{ Pro $\alpha 1(\mathrm{l})$ collagen mRNA } & \multicolumn{3}{|c|}{$\gamma$-Actin mRNA } \\
\hline & \multicolumn{2}{|c|}{ Endothelial cells } & \multicolumn{4}{|c|}{ Tension } & \multirow[b]{2}{*}{$\% \Delta$} & \multicolumn{2}{|c|}{ Tension } & \multirow[b]{2}{*}{$\% \Delta$} \\
\hline & With & Without & 100 & 50 & 25 & 10 & & 50 & 10 & \\
\hline & & & \multicolumn{4}{|c|}{$m m H g$} & & \multicolumn{3}{|c|}{$\mathrm{mmHg}$} \\
\hline $1 \mathrm{~A}$ & $\mathbf{x}$ & & - & - & - & 27 & \multirow{2}{*}{+12} & - & 40 & \multirow{2}{*}{-4} \\
\hline B & $\mathbf{x}$ & & - & - & - & 31 & & - & 36 & \\
\hline $2 \mathrm{~A}$ & $\mathbf{x}$ & & - & - & - & 30 & \multirow{2}{*}{+52} & - & 5 & \multirow{2}{*}{+8} \\
\hline B & $\mathbf{x}$ & & - & 46 & - & - & & 6 & - & \\
\hline $3 \mathrm{~A}$ & $\mathbf{x}$ & & - & - & - & 12 & \multirow{2}{*}{+83} & - & 22 & \multirow{2}{*}{+13} \\
\hline B & $\mathbf{x}$ & & - & 27 & - & - & & 25 & - & \\
\hline $4 \mathrm{~A}$ & & $\mathbf{x}$ & - & - & - & 32 & \multirow{2}{*}{-7} & - & 22 & \multirow{2}{*}{+9} \\
\hline B & & $\mathbf{x}$ & - & 30 & - & - & & 24 & - & \\
\hline $5 \mathrm{~A}$ & $\mathbf{x}$ & & - & - & - & 9 & \multirow{2}{*}{+53} & - & - & \multirow{2}{*}{-} \\
\hline B & $\mathbf{x}$ & & 13 & - & - & - & & - & - & \\
\hline $6 \mathrm{~A}$ & $\mathbf{x}$ & & - & - & - & 36 & \multirow{2}{*}{+28} & - & 29 & \multirow{2}{*}{+3} \\
\hline B & $x$ & & - & - & 46 & - & & $30^{\ddagger}$ & - & \\
\hline $7 \mathrm{~A}$ & $\mathbf{x}$ & & - & - & - & 23 & \multirow{2}{*}{+4} & - & 30 & \multirow{2}{*}{-3} \\
\hline B & & * & - & - & - & 24 & & - & 29 & \\
\hline $8 \mathrm{~A}$ & $\mathbf{x}$ & & - & 34 & - & - & \multirow{2}{*}{-3} & - & - & \multirow{2}{*}{-} \\
\hline B & & $*$ & - & 33 & - & - & & - & - & \\
\hline
\end{tabular}

Data are results from RNA extracted from 15 to 20 pulmonary arteries for each group. Numbers are slopes of slot blot analyses in dpm $\times 10^{2} / 100 \mathrm{ng}$ total RNA per slot. $\% \Delta$ is ([slope of experiment - slope of control]/slope of control) $\times 100$. Control refers to value obtained for $10 \mathrm{mmHg}$ tension (except the $50-\mathrm{mmHg}$ value for group 8 is considered control). ${ }^{*}$ Endothelial cells removed after $4 \mathrm{~h}$ of tension. ${ }^{\ddagger} \mathrm{Result}$ for $25 \mathrm{mmHg}$.

tension. Group 4 was used to test the effect of removing the endothelium on procollagen mRNA levels after application of $50 \mathrm{mmHg}$ tension. Groups 5 and 6 tested the effect of 100 and $25 \mathrm{mmHg}$ tension, respectively. Groups 7 and 8 were used to determine whether the level of procollagen mRNA remained unchanged after removal of the endothelium. Groups 3 and 4 were also used to assess whether the v-sis mRNA level was increased by $50 \mathrm{mmHg}$ tension and whether the increased mRNA level was reduced by removal of the endothelium.

Tissue from paired jugular veins and aortas was used to measure procollagen and actin mRNA levels after application of mechanical tension. Only tissues with intact endothelium were studied. Jugular veins were assessed at $10 \mathrm{mmHg}$ tension to approximate mean venous pressure and at $80 \mathrm{mmHg}$ to simulate the mean systemic BP of a coronary artery venous allograft. Aortic segments were assessed at 0 , 80 , and $160 \mathrm{mmHg}$ tensions; $80 \mathrm{mmHg}$ is the mean arterial BP of a normal rat and $160 \mathrm{mmHg}$ that of a spontaneously hypertensive rat (26).

Statistical analysis. Values are mean \pm SEM, except for quantitative mRNA data, which were from pooled samples. A paired $t$ test (27) was used to analyze data of paired tissues. Two-way analysis of variance was done using ANOVA (28) followed by a Duncan's post-hoc test (29). Correlations of data were made by linear regression analysis using the least squares method and analyzed by the standard error of the estimate ( $r$ (30). A $P$ value $<0.05$ was considered significant.

\section{Results}

Animals. Pulmonary arteries from 94 animals were used for protein synthesis, LDH activity measurements and microscopy and from 305 animals (15-20 pooled per group) for extraction of RNA. 25 animals were used to obtain aortas and jugular veins. In 18 representative animals selected at random, mean right ventricular pressure $(9.4 \pm 0.4$ [SEM] $\mathrm{mmHg})$, he- matocrit $(41 \pm 1 \%)$, and the ratio of weights of the right ventricle to left ventricle plus septum $(0.25 \pm 0.02)$ were within the normal range for adult rats (10).

Tissues. For segments of pulmonary arteries in the representative group $(n=18)$, there was no difference in the average weights (control, $6.1 \pm 0.4 \mathrm{mg}$; tension, $6.4 \pm 0.4 \mathrm{mg}$ ), lengths (control, $2.8 \pm 0.1 \mathrm{~mm}$; tension, $2.7 \pm 0.1 \mathrm{~mm}$ ) or radii $(0.1 \pm 0.1$ $\mathrm{cm}$ for both groups). The average load applied to produce an equivalent BP for $100 \mathrm{mmHg}$ was $2.6 \pm 0.2 \mathrm{~g}$, for $50 \mathrm{mmHg}$ was $1.3 \pm 0.1 \mathrm{~g}$, for $25 \mathrm{mmHg}$ was $0.7 \pm 0.1 \mathrm{~g}$, and for $10 \mathrm{mmHg}$ was $0.3 \pm 0.1 \mathrm{~g}$. The corresponding circumferential wall tension for $100 \mathrm{mmHg}$ was $12.3 \pm 0.2 \mathrm{dyn} / \mathrm{cm}$, for $50 \mathrm{mmHg}$ was $5.8 \pm 0.2 \mathrm{dyn} / \mathrm{cm}$, and for $10 \mathrm{mmHg}$ was $1.3 \pm 0.1 \mathrm{dyn} / \mathrm{cm}$.

Collagen synthesis. In segments with intact endothelium, the rate of collagen synthesis was increased by $35 \pm 9 \%$ in segments with $50 \mathrm{mmHg}$ tension compared to $10 \mathrm{mmHg}$ tension (Fig. $1 A)(n=10, P<0.05)$. In five of six segments with the endothelium removed, the rate of collagen synthesis was less at $50 \mathrm{mmHg}$ than $10 \mathrm{mmHg}$ tension (Fig. $1 \mathrm{~B}$ ). However, the mean values of $2.0 \pm 0.5$ and $1.5 \pm 0.2 \times 10^{2} \mathrm{dpm} /(\mathrm{mg}$ protein $\cdot h)$ were not significantly different $(P<0.2)$.

Elastin synthesis. In segments with intact endothelium, the rate of elastin synthesis was increased by $110 \pm 17 \%$ at 50 mmHg compared with $10 \mathrm{mmHg}$ tension $(n=5, P<0.05)$ (Fig. $2 A$ ). In segments with the endothelium removed, 50 $\mathrm{mmHg}$ tension produced no significant increase in elastin synthesis $(n=5)$ (Fig. $2 B)$.

Thymidine incorporation. Tension of $50 \mathrm{mmHg}$ did not increase the rate of $\left[{ }^{3} \mathrm{H}\right]$ thymidine incorporation into DNA in segments with intact $(n=10)$ (Fig. $3 A)$ or denuded $(n=8)$ (Fig. $3 B$ ) endothelium compared to $10 \mathrm{mmHg}$. 
A WITH ENDOTHELIUM

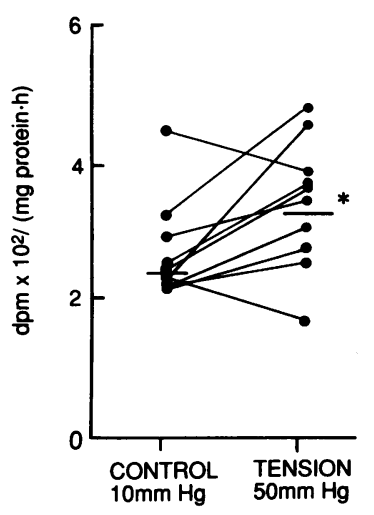

B WITHOUT ENDOTHELIUM

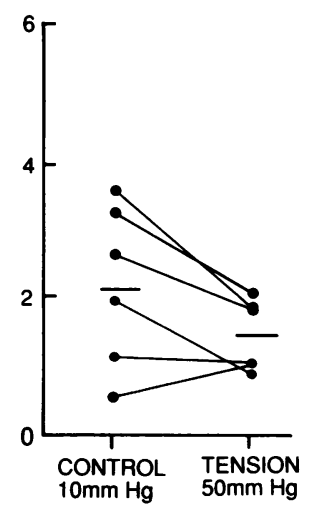

Figure 1. Collagen synthetic rate. $\left[{ }^{14} \mathrm{C}\right]$ Proline incorporation into $\left[{ }^{14} \mathrm{C}\right]$ hydroxyproline in vessel segments after application of tension. The data points joined by a line indicate paired vessels. $(A)$ Segments with intact endothelium; $(B)$ segments with endothelium removed. Bar, mean values; asterisk, $P<0.05$ compared to control.

$L D H$ activity. In segments with intact endothelium, tensions of $250 \mathrm{mmHg}$ and $50 \mathrm{mmHg}(n=10$ each) produced no measurable LDH activity in the medium. Removal of the endothelium produced increased LDH activity with no tension applied $(5.9 \pm 2.9 \%$ of total tissue activity) $(n=6, P<0.05)$ and at $50 \mathrm{mmHg}$ tension $(6.8 \pm 3.3 \%$ of total tissue activity) $(n=5$, $P<0.05$ ).

Endothelium-dependent relaxation. Acetylcholine induced complete relaxation in all rings with endothelium $(100 \pm 2 \%$, $\mathrm{IC}_{50}$ value $5 \pm 1 \times 10^{-8} \mathrm{M}, n=12$ ).

Scanning electron microscopy. Endothelial cell coverage was complete in the rings removed intact whereas areas of complete endothelial cell denudation were apparent in the vessels that had been rubbed (not shown).

\section{A WITH ENDOTHELIUM}

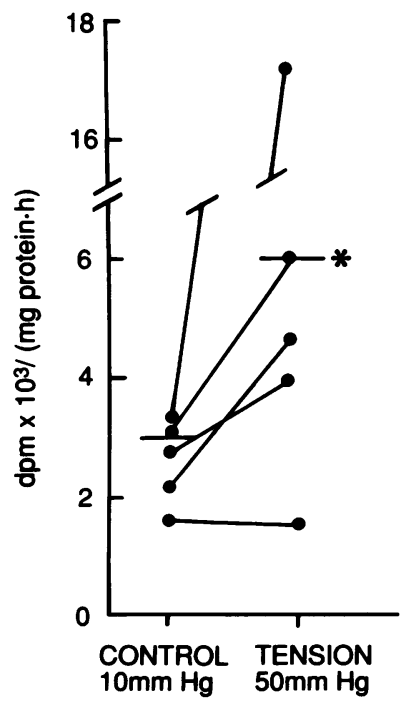

\section{B WITHOUT ENDOTHELIUM}

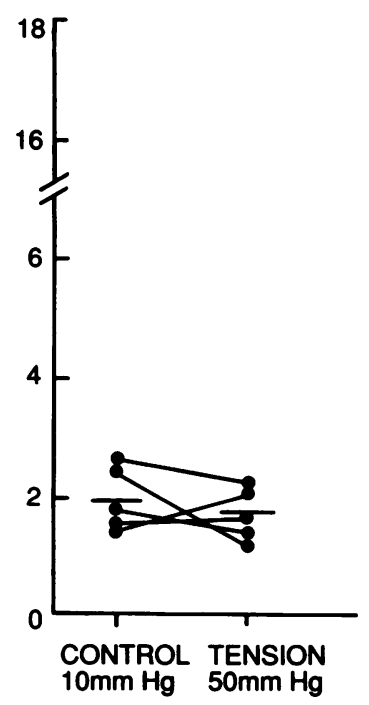

Figure 2. Elastin synthetic rate. $\left[{ }^{14} \mathrm{C}\right]$ Valine incorporation into insoluble elastin. Format same as Fig. 1. (A) Segments with intact endothelium; $(B)$ segments with endothelium removed. Bar, mean values; asterisk, $P<0.05$ compared to control.

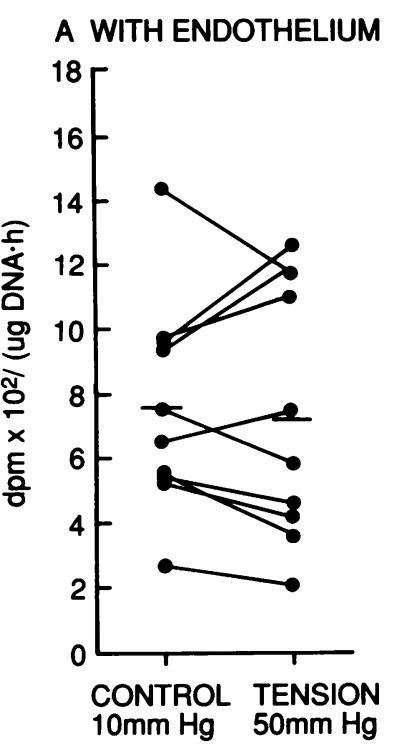

B WITHOUT ENDOTHELIUM

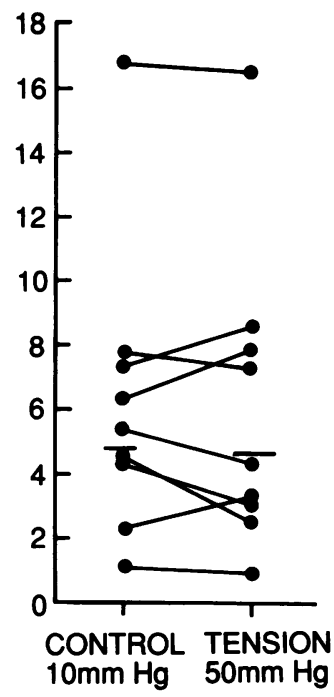

Figure 3. $\left[{ }^{3} \mathrm{H}\right]$ Thymidine incorporation into DNA. Format same as Fig. 1. (A) Segments with intact endothelium; $(B)$ segments with endothelium removed. Bar, mean values.

Northern blot analysis. Northern blot analysis of total RNA extracted from pulmonary arteries showed a single 4.8kb band for pro $\alpha 1(\mathrm{I})$, consistent with the mRNA transcript for rat type I procollagen (22). For $\mathrm{v}$-sis, a single 3.5-kb band was found consistent with the size of the v-sis transcript (31) compared to $\lambda$ RNA/Hind III molecular weight size markers (not shown).

Collagen and actin $m R N A$. Autoradiograms of filters hybridized with probes for pro $\alpha 1(\mathrm{I})$ collagen showed increased signal intensity in RNA extracted from pulmonary arteries with $50 \mathrm{mmHg}$ tension compared to $10 \mathrm{mmHg}$ tension (Fig. 4 $A$ ). There appeared to be a less marked increase in the signal intensity for actin in RNA from the same tissues (Fig. $4 \mathrm{~A}$ ). In contrast, in RNA extracted from segments without endothelium, there was no detectable difference in the signal intensity for procollagen or actin mRNAs using RNA from tissues after application of $50 \mathrm{mmHg}$ compared to $10 \mathrm{mmHg}$ tension (Fig. $4 B$ ).

Quantitation of steady-state mRNA levels of the slot blot analyses for groups 1-8 using radiolabeled probes for pro $\alpha 1$ (I) collagen and $\gamma$-actin are shown in Table I. The results can be summarized as follows. (Group 1) Duplicate measurements at $10 \mathrm{mmHg}$ tension differed by $12 \%$ for procollagen and $4 \%$ for actin. (Groups 2 and 3) $50 \mathrm{mmHg}$ tension increased procollagen mRNA levels by 52 and $83 \%$, respectively, and had little effect on actin. (Group 4) Removal of the endothelium blunted the tension-induced increase in procollagen mRNA level. (Groups 5 and 6) Tensions of 100 and $25 \mathrm{mmHg}$ appeared to increase procollagen; $25 \mathrm{mmHg}$ tension had little effect on actin mRNA level. (Groups 7 and 8) Removal of the endothelium after application of 10 and $50 \mathrm{mmHg}$ tension for $4 \mathrm{~h}$ produced similar changes in procollagen mRNA levels compared to rings with intact endothelium; no change in actin mRNA level was apparent after removal of endothelium at 10 mmHg tension.

Quantitation of proal(I) collagen mRNA in total RNA extracted from jugular veins (15-20 per group) showed the 


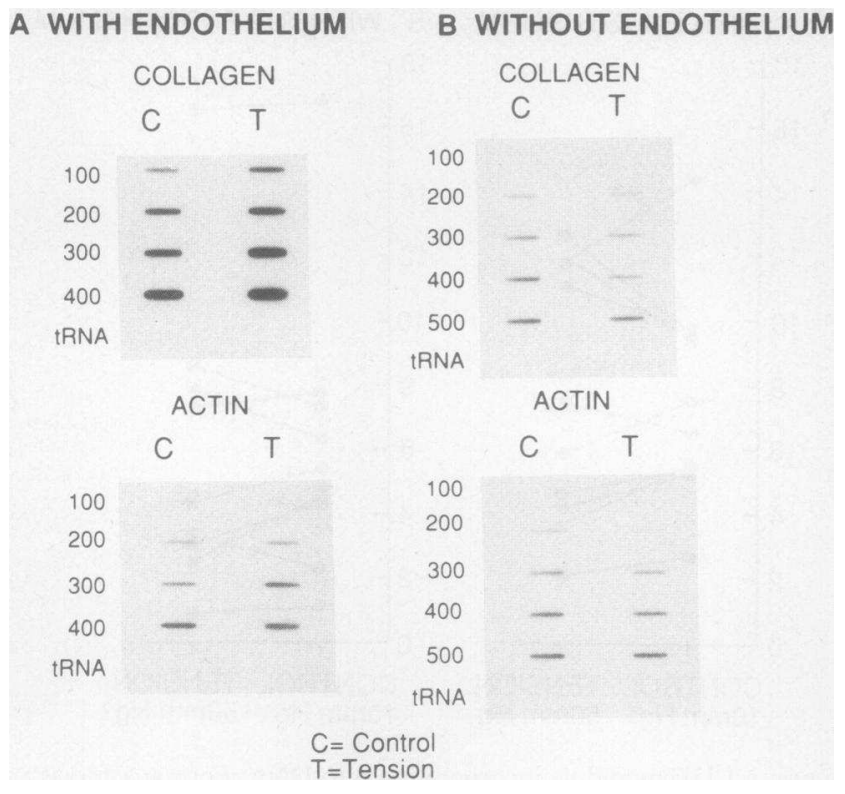

Figure 4. Autoradiogram of filter hybridized with ${ }^{32} \mathrm{P}$-labeled pro $\alpha 1(\mathrm{I})$ collagen and $\gamma$-actin probes. $(A)$ RNA from segments with endothelium intact; $(B)$ RNA from segments with endothelium removed. Abbreviations: $\mathrm{C}, 10 \mathrm{mmHg}$ tension applied to segment for 4 h; T, $50 \mathrm{mmHg}$ tension applied to segment for $4 \mathrm{~h}$; tRNA, transfer RNA. Numbers, ng total RNA applied per slot.

following values (dpm $\left.\times 10^{2} / 100 \mathrm{ng} \mathrm{RNA}\right): 10 \mathrm{mmHg}, 5 ; 80$ $\mathrm{mmHg}, 7(\% \Delta,+42 \%)$. For procollagen for aorta: $0 \mathrm{mmHg}$, $15 ; 80 \mathrm{mmHg}, 19 ; 160 \mathrm{mmHg}, 14(\% \Delta,-26 \%)$. For actin for aorta: $80 \mathrm{mmHg}, 52 ; 160 \mathrm{mmHg}, 43(\% \Delta,-17 \%)$. These results suggest that there was no stimulation of pro $\alpha$ (I) collagen in the vein or aorta.

$V$-sis $m R N A$. Quantitation of the mRNA levels for v-sis (expressed as dpm $\times 10^{2} / 100 \mathrm{ng}$ RNA) showed: for intact segments with $50 \mathrm{mmHg}$ tension, 99 ; for $10 \mathrm{mmHg}$ tension, $58(\% \Delta,+71 \%)$ (Fig. 5). For denuded segments, $50 \mathrm{mmHg}$ tension, $113 ; 10 \mathrm{mmHg}$ tension, $141(\% \Delta,-20)$.

\section{Discussion}

We found that static mechanical tension applied to intact segments of main pulmonary arteries increased incorporation of $\left[{ }^{14} \mathrm{C}\right]$ proline into collagen and $\left[{ }^{14} \mathrm{C}\right]$ valine into insoluble elastin and increased the steady-state mRNA level for type I procollagen. The new finding here is that a surprisingly short period of tension $(4 \mathrm{~h})$ was required to stimulate collagen and elastin synthesis. Hume (11) found that static tension applied to isolated rabbit ear arteries required 3-4 d for enhanced $\left[{ }^{14} \mathrm{C}\right]-$ proline uptake and $\left[{ }^{3} \mathrm{H}\right]$ thymidine incorporation into DNA. In agreement with Hume's results, we found short-term (4 h) tension produced no increased type I procollagen mRNA levels in aortas. The magnitude of changes in veins was small and probably did not indicate a response to tension. The pulmonary artery, a vessel more distensible than the aorta (32), may respond to mechanical tension by more rapid production of collagen to limit tissue deformation.

We also found that for a particular level of mechanical tension the percent increase in pro $\alpha 1$ (I) collagen mRNA was consistently greater than the corresponding change in levels of $\gamma$-actin mRNA. Since the $\gamma$-actin mRNA encodes a cellular protein, these results suggest that the early response to mechanical tension is relatively specific for enhanced production of extracellular connective tissue proteins.

A major finding of this study is that an intact endothelium is required for tension-induced increases in connective tissue proteins. In segments that had been denuded of endothelium before application of mechanical tension, collagen and elastin synthesis and mRNA levels for type I procollagen were not increased. One explanation of this result is that endothelial cells are a major source of the increased connective tissue production. We think this is unlikely for two reasons. First, removal of the endothelium after $4 \mathrm{~h}$ of tension made no difference in the mRNA level for type I procollagen. Second, smooth muscle cells and adventitial fibroblasts are considered to be the major sources of interstitial collagen and elastin production in blood vessels (33). It is also possible that removal of the endothelium altered the passive mechanical properties of the vessel segment so that the applied tension was less than that produced with intact endothelium. This is unlikely, however, since removal of the endothelium has no effect on resistance to passive deformation of isolated blood vessels (34).

Injury produced by removing the endothelium may have impaired the ability of the tissue to respond to mechanical tension. We found no evidence of injury in tissues with intact endothelium by release of LDH activity, but minimal injury was produced by removing the endothelium. Although we cannot exclude the possibility that injury impaired the ability of the denuded segment to respond to mechanical tension, this is unlikely since our results show that denuded segments synthesize collagen and elastin at the same rates as nondenuded segments at equivalent levels of tension $(10 \mathrm{mmHg})$.

Langille and O'Donnell (35) proposed that an endothelial cell-derived factor is involved in vascular remodeling. Four weeks after carotid artery ligation in dogs, the vessels underwent a fixed structural change refactory to vasodilators, but in arteries denuded of endothelium prior to carotid ligation remodeling did not occur. A platelet-derived growth factor (PDGF)-like mitogen produced by endothelial cells was suggested as the mediator involved since PDGF is able to stimulate smooth muscle cell proliferation (36).

We studied whether PDGF levels in pulmonary artery segments were increased by mechanical tension by measuring the level of v-sis, a protooncogene that encodes a protein with almost complete homology to the B chain of PDGF (8). In segments with mechanical tension applied, the level of mRNA for v-sis was increased, and this induction did not occur in segments denuded of endothelial cells. The presence of v-sis mRNA in segments denuded of endothelium is probably derived from other vascular cells since PDGF-like material can be made by a variety of cell types including vascular smooth muscle cells $(37,38)$.

The increased v-sis expression was related to connective tissue synthesis in the absence of cell proliferation. The short labeling period $(4 \mathrm{~h})$ may explain why cell proliferation was not observed; vascular smooth muscle cells (39) and fibroblasts (40) require longer periods to progress through the cell cycle. Mechanical tension may have stimulated the release of several substances since PDGF alone would not be expected to increase synthesis of connective tissue in the absence of cell proliferation. Transforming growth factor- $\beta$ (TGF- $\beta$ ) (41) and basic fibroblast growth factor (bFGF) (42) stimulate connec- 


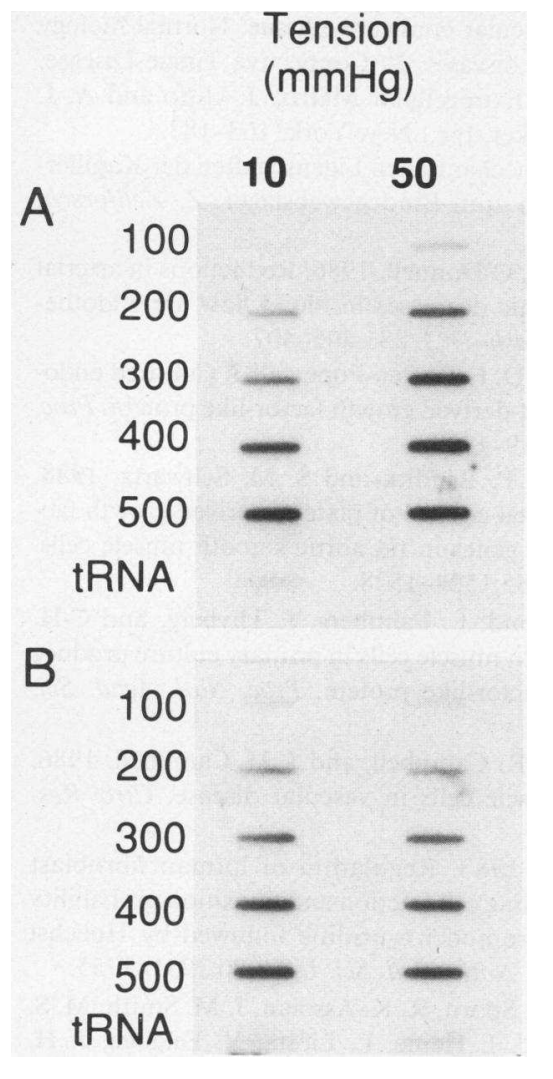

Figure 5. Autoradiogram of filter hybridized with a ${ }^{32} \mathrm{P}$-labeled probe for v-sis protooncogene. Total RNA extracted from segments with tension of 10 or $50 \mathrm{mmHg}$ applied for $4 \mathrm{~h}$. Abbreviations as in Fig. 4. Numbers, ng total RNA applied per slot.

tive tissue synthesis, and these factors also regulate the expression of cellular oncogenes $(42,43)$. Release of TGF- $\beta$ or bFGF may cause both expression of $\mathrm{v}$-sis and connective tissue synthesis in vascular rings under mechanical tension.

Experimental studies suggest that mechanical factors influence connective tissue synthesis in vascular tissues. Blood vessels that sustain the highest tangential tensions have the greatest abundance of collagen and elastin fibers in their walls (44), and vessels with the greatest pulsatile distension have the highest rates of collagen synthesis (45). Arteries but not veins of animals with experimental systemic hypertension have increased collagen synthesis (46), and in newborn calves with hypoxic pulmonary hypertension elastin synthesis is increased in pulmonary arteries but not aortas (6). Banding one pulmonary artery in rats exposed to hypoxia prevents remodeling on the banded but not the unbanded side (47), suggesting that pressure and flow and not hypoxia are necessary for remodeling. Other studies suggest that mechanical forces act directly on nonendothelial cells in blood vessel walls to stimulate connective tissue synthesis. For example, cyclical stretching of vascular smooth muscle cells grown on extensible membranes results in stimulation of collagen and mucopolysaccharide synthesis (7). These experiments suggest that mechanical tension is an important physiologic stimulus for vascular remodeling.

Vascular tissue may respond to mechanical stimuli by production of growth or differentiation factors that affect remodeling of the blood vessel wall. Hansson and associates (48) showed that immunoreactive insulin-like growth factor-I is expressed by vascular smooth muscle cells by wall stress. Meacham and colleagues (6) have demonstrated a smooth muscle cell-derived factor in cells grown from pulmonary arteries of

calves with hypoxic pulmonary hypertension which selectively stimulates elastin production; hypoxia or increased pressure was postulated to be the stimulus for release of this factor. We found that pulmonary vascular endothelial cells respond to mechanical tension by producing a PDGF-like material. In preliminary studies, we showed that a 4-h application of hydrostatic pressure $(50 \mathrm{mmHg})$ to cultured pulmonary artery endothelial cells induces v-sis expression (49). Taken together, these findings suggest that certain vascular cells respond to an applied load by elaborating factors that affect growth and matrix production of surrounding cells in the blood vessel wall.

In conclusion, we have shown that mechanical tension causes surprisingly rapid induction of vascular connective tissue synthesis, which appears to be mediated by release of factors from endothelial cells. This mechanism might account in part for the early structural adaptation of central pulmonary arteries to elevated blood pressure.

\section{Acknowledgments}

We thank Sandra A. Belsky, Carol L. Ruppert, Sandra Hayes, Robert Dean, and James M. Sumka for technical assistance, Dr. David E. Birk for the electron microscopic studies and Marcella Spioch for preparation of the manuscript.

This work was supported by U. S. Public Health Service grants HL-24264, HL-07467 and AM-22051, the Barbara Wallace Cornwall Respiratory Research Laboratory, the John M. Kent Pulmonary Fibrosis Fund, the American Heart Association/New Jersey Affiliate and the Medical Research Service of the Veterans Administration.

\section{References}

1. Wagenvoort, C. A., and N. Wagenvoort. 1979. Pulmonary vascular bed: normal anatomy and responses to disease. In Pulmonary Vascular Diseases. K. M. Moser, editor. Marcel Dekker, Inc., New York. 1-109.

2. Rodbard, S. 1970. Negative feedback mechanisms in the architecture and function of the connective and cardiovascular tissues. Perspect. Biol. Med. 13:507-527.

3. Fry, D. L. 1968. Acute vascular endothelial changes associated with increased blood velocity gradients. Circ. Res. 22:165-197.

4. Esterly, J. A., S. Glagov, and D. J. Ferguson. 1968. Morphogenesis of intimal obliterative hyperplasia of small arteries in experimental pulmonary hypertension. An ultrastructural study of the role of smooth muscle cells. Am. J. Pathol. 52:325-347.

5. Duncan, L. E., Jr., K. Buck, and A. Lynch. 1965. The effect of pressure and stretching on the passage of labeled albumin into the canine aortic wall. J. Atheroscler. Res. 5:69-79.

6. Mecham, R. P., L. A. Whitehouse, D. S. Wrenn, W. C. Parks, G. L. Griffin, R. M. Senior, E. C. Crouch, K. R. Stenmark, and N. F. Voelkel. 1987. Smooth muscle-mediated connective tissue remodeling in pulmonary hypertension. Science (Wash. DC). 237:423-426.

7. Leung, D. Y., S. Glagov, and M. B. Matthews. 1976. Cyclic stretching stimulates synthesis of matrix components by arterial smooth muscle cells in vitro. Science (Wash. DC). 191:475-477.

8. Josephs, S. F., C. Guo, L. Ratner, and F. Wong-Staal. 1984. Human-proto-oncogene nucleotide sequences corresponding to the transforming region of simian sarcoma virus. Science (Wash. DC). 223:487-491.

9. Maniatis, T., E. F. Fritsch, and J. Sambrook. 1982. Molecular Cloning. A Laboratory Manual. Cold Spring Harbor Laboratory, Cold Spring Harbor, NY. 202,448.

10. Kerr, J. S., D. J. Riley, M. M. Frank, R. L. Trelstad, and H. M. Frankel. 1984. Reduction of chronic hypoxic pulmonary hypertension in the rat by beta-aminopropionitrile. J. Appl. Physiol. 57:1760-1766.

11. Hume, W. R. 1980. Proline and thymidine uptake in rabbit ear 
artery segments in vitro increased by chronic tangential load. Hypertension. 2:738-743.

12. Burton, A. C. 1951. On the physical equilibrium of small blood vessels. Am. J. Physiol. 164:319-329.

13. Juva, K., and D. J. Prockop. 1966. Modified procedure for the assay of $\left[{ }^{3} \mathrm{H}\right]$ or $\left[{ }^{14} \mathrm{C}\right]$ hydroxyproline. Anal. Biochem. 15:77-83.

14. Keeley, F. W., and D. J. Johnson. 1986. The effect of developing hypertension on the synthesis and accumulation of elastin in the aorta of the rat. Biochem. Cell Biol. 64:38-43.

15. Moore, S., and W. H. Stein. 1948. Photometric ninhydrin method for use in chromatography of amino acids. J. Biol. Chem. 176:367-388.

16. Bradford, M. M. 1976. A rapid and sensitive method for the quantitation of microgram quantities of protein utilizing the principle of protein-dye binding. Anal. Biochem. 72:248-254.

17. Hinegardner, R. T. 1971. An improved fluorometric assay for DNA. Anal. Biochem. 39:197-201.

18. Wroblewski, F., and J. S. LaDue. 1955. Lactic dehydrogenase activity in blood. Proc. Soc. Exp. Biol. Med. 90:210-213.

19. Furchgott, R. F., and J. V. Zawadzki. 1980. The obligatory role of endothelial cells in the relaxation of arterial smooth muscle by acetylcholine. Nature (Lond.). 288:373-376.

20. Glisin, V., R. Crkvenjakov, and C. Byus. 1974. Ribonucleic acid isolated by cesium chloride centrifugation. Biochemistry. 13:2633-2637.

21. Technical Bulletin and Product Profile Publication. 1984. Riboprobe Gene Analysis System. Promega Biotec, Madison, WI.

22. Pierce, R. A., M. R. Glaug, R. S. Greco, J. W. Mackenzie, C. D. Boyd, and S. B. Deak. 1987. Increased procollagen mRNA levels in carbon tetrachloride-induced liver fibrosis in rats. J. Biol. Chem. 262:1652-1658.

23. Bernard, M. P., J. C. Myers, M. L. Chu, F. Ramirez, E. F. Eikenberry, and D. J. Prockop. 1983. Structure of a cDNA for the pro 2 chain of human type I procollagen. Comparison with chick cDNA for pro $\alpha 1(\mathrm{I})$ identifies structurally conserved features of the protein and the gene. Biochemistry. 22:1139-1145.

24. Ponte, P., P. Gunning, H. Blau, and L. Kedes. 1983. Human actin genes are single copy alpha-skeletal and alpha-cardiac but multicopy for beta- and gamma-cytoskeletal genes: 3'-untranslated regions are isotype specific but are conserved in evolution. Mol. Cell Biol. 3:1783-1791.

25. Devard, S. G., E. P. Reddy, J. D. Law, K. C. Robbins, and S. A. Aaronson. 1983. Nucleotide sequence of the simian sarcoma virus genome. Demonstration that its acquired cellular sequences encode the transforming gene product $\mathrm{p} 28^{\text {sis }}$. Proc. Natl. Acad. Sci. USA. 80:731-735.

26. Okamoto, K., and K. Aoki. 1963. Development of a strain of spontaneously hypertensive rats. Jpn. Circ. J. 27:282-293.

27. Ferguson, G. A. 1966. Statistical Analysis in Psychology and Education. McGraw-Hill Book Co., New York. 206-207.

28. SAS User's Guide. 1982. Statistics. SAS Institute, Inc., Carey, NC. 119-137.

29. Duncan, D. B. 1975. T tests and intervals for comparisons suggested by the data. Biometrics. 31:339-359.

30. Zar, J. H. 1974. Biostatistical Analysis. Prentice-Hall, Englewood Cliffs, NJ. 198-227.

31. Collins, T., D. Ginsburg, J. M. Boss, S. H. Orkin, and J. S. Pober. 1985. Cultured human endothelial cells express platelet-derived growth factor B chain: cDNA cloning and structural analysis. Nature (Lond.). 316:748-750.

32. Cox, R. H. 1982. Comparison of mechanical and chemical properties of extra- and intralobar canine pulmonary arteries. Am. J. Physiol. 242:H245-H253.
33. Mayne, R. 1987. Vascular connective tissue. Normal biology and derangement in human diseases. In Connective Tissue Disease. Molecular Pathology of the Extracellular Matrix. J. Uitto and A. J. Perejda, editors. Marcel Dekker, Inc., New York. 163-183.

34. Nagel, A. 1934. Die mechanischen Eigenschaften der Kapillerwand und ihre Bezeihungen zum Bindegewebslager. Z. Zellforsch. 21:376-387.

35. Langille, B. L., and F. O'Donnell. 1986. Reductions in arterial diameter produced by chronic decreases in blood flow are endothelium-dependent. Science (Wash. DC). 231:405-407.

36. DiCorleto, P. E., and D. F. Bowen-Pope. 1983. Cultured endothelial cells produce a platelet-derived growth factor-like protein. Proc. Natl. Acad. Sci. USA. 80:1919-1923.

37. Majesky, M. W., E. P. Benditt, and S. M. Schwartz. 1988. Expression and developmental control of platelet-derived growth factor A-chain and B-chain/sis genes in rat aortic smooth muscle cells. Proc. Natl. Acad. Sci. USA. 85:1524-1528.

38. Nilsson, J., M. Sjölund, L. Palmberg, J. Thyberg, and C-H. Heldin. 1985. Arterial smooth muscle cells in primary culture produce a platelet-derived growth factor-like protein. Proc. Natl. Acad. Sci. USA. 82:4418-4422.

39. Schwartz, S. M., G. R. Campbell, and J. H. Campbell. 1986. Replication of smooth muscle cells in vascular disease. Circ. Res. 58:427-444.

40. Rabinovitch, P. S. 1983. Regulation of human fibroblast growth rate by both non-cycling cell fraction and transition probability is shown by growth in 5-bromodeoxyuridine followed by Hoechst 33258 flow cytometry. Proc. Natl. Acad. Sci. USA. 80:2951-2955.

41. Roberts, A. B., M. B. Sporn, R. K. Assoian, J. M. Smith, M. S. Roche, L. M. Wakefield, U. I. Heine, L. Liotta, V. Falanga, J. H. Kehrl, and A. S. Fauci. 1986. Transforming growth factor type B. Rapid induction of fibrosis and angiogenesis in vivo and stimulation of collagen formation in vitro. Proc. Natl. Acad. Sci. USA. 83:4167-4171.

42. Gospodarowicz, D. 1985. Biological activity in vivo and in vitro of pituitary and brain fibroblast growth factor. In Mediators in Cell Growth and Differentiation. R. J. Ford and A. L. Maizel, editors. Raven Press, New York. 109-134.

43. Leof, E. B., J. A. Proher, A. S. Goustin, G. D. Shipley, P. E. DiCorleto, and H. L. Moses. 1987. Induction of c-sis mRNA and activity similar to platelet-derived growth factor by transforming growth factor-beta. A proposed model for indirect mitogenesis involving autocrine activity. Proc. Natl. Acad. Sci. USA. 83:2453-2457.

44. Fischer, G. M., and J. G. Llaurado. 1966. Collagen and elastin content in canine arteries selected from functionally different vascular beds. Circ. Res. 19:395-399.

45. Fischer, G. M., M. L. Swain, and K. Cherian. 1980. Pulsatile distension and vascular collagen synthesis in the rabbit. Blood Vessels. 17:216-220.

46. Iwatsuki, K., G. J. Cardinale, S. Spector, and S. Udenfriend. 1977. Hypertension: Increase of collagen biosynthesis in arteries but not in veins. Science (Wash. DC). 198:403-405.

47. Rabinovitch, M., M. A. Konstam, W. J. Gamble, N. Papanicolaou, M. J. Aronovitz, S. Treves, and L. Reid. 1983. Changes in pulmonary blood flow affect vascular response to chronic hypoxia in rats. Circ. Res. 52:432-441.

48. Hansson, H-A., E. Jennische, and A. Skottner. 1987. IGF-I expression in blood vessels varies with vascular load. Acta Physiol. Scand. 129:165-169.

49. Riley, D., and J. Gullo. 1988. Pressure applied to cultured pulmonary artery endothelial cells causes release of a fibroblast mitogen and induces a proto-oncogene. FASEB (Fed. Am. Soc. Exp. Biol.) J. 2:300a. (Abstr.) 